\title{
Molecular and morphological characterization of hydrochar produced by microwave-assisted hydrothermal carbonization of cellulose
}

\author{
Marcela Guiotoku(1), Fabricio Augusto Hansel(1), Etelvino Henrique Novotny(2) \\ and Claudia Maria Branco de Freitas Maia(1)
}

\begin{abstract}
(1)Embrapa Florestas, Estrada da Ribeira, Km 111, CEP 83411-000 Colombo, PR, Brazil. E-mail: marcelaguiotoku@gmail.com, hansel@cnpf.embrapa.br, claudia.maia@cnpf.embrapa.br (2)Embrapa Solos, Rua Jardim Botânico, no 1.024, Jardim Botânico, CEP 22460-000 Rio de Janeiro, RJ, Brazil. E-mail: etelvino@cnps.embrapa.br
\end{abstract}

\begin{abstract}
The objective of this work was to characterize the morphology and molecular composition of the hydrochar produced by microwave-assisted hydrothermal carbonization of cellulose. The produced hydrochar consists mainly of aggregate microspheres with about $2.0 \mu \mathrm{m}$ in diameter, with aliphatic and aromatic structures and the presence of carbonyl functional groups. The aromatic groups are formed mainly by benzofuran-like structures, being chemically different from common cellulose char. Microwave-assisted hydrothermal carbonization yields a functionalized carbon-rich material similar to that produced by the conventional hydrothermal process.

Index terms: anthropogenic dark earth of Amazonia, biochar, charcoal, gas chromatography, mass spectrometry, nuclear magnetic resonance.

\section{Caracterização molecular e morfológica do hidrocarvão produzido por carbonização hidrotérmica da celulose em micro-ondas}

\begin{abstract}
Resumo - O objetivo deste trabalho foi caracterizar a morfologia e a estrutura molecular do hidrocarvão produzido pela carbonização hidrotérmica da celulose por micro-ondas. $\mathrm{O}$ hidrocarvão produzido consiste principalmente de microesferas agregadas de aproximadamente $2,0 \mu \mathrm{m}$ de diâmetro, com estruturas alifáticas e aromáticas e a presença de grupos funcionais carbonilas. Os grupos aromáticos são constituídos basicamente de estruturas do tipo benzofurano, com estrutura química diferente da do carvão obtido da celulose por métodos convencionais. A carbonização hidrotérmica da celulose por micro-ondas produz um material funcionalizado rico em carbono, semelhante ao produzido por métodos hidrotérmicos convencionais.
\end{abstract}

Termos para indexação: terra preta de índio, "biochar", carvão vegetal, cromatografia gasosa, espectrometria de massa, ressonância magnética nuclear.

\section{Introduction}

Commonly, biochar is obtained from the partial transformation of biomass (carbon source-like wood, straw, agricultural and forest residues) in coal-like material by thermal decomposition in the absence or at a low concentration of oxygen. The resulting material is partly degraded lignocellulosic products composed by smaller molecules trapped into a polymeric matrix (Bridgwater, 2003). Once in the soil, the biochar functionalization is a time-consuming process that occurs naturally over a long period of time, as observed in the anthropogenic dark earth of Amazonia (Novotny et al., 2009; Glaser \& Birk, 2012). Therefore, methods for the production and conversion of waste biomass into a highly functionalized biochar are a current challenge.
Hydrothermal carbonization (HTC) can be defined as a thermochemical process for converting biomass to produce a solid coal-like product (Funke \& Ziegler, 2010). One advantage of HTC is the possibility to carbonize feedstock with high moisture contents in a carbonaceous solid without requiring the drying step, which results in a more cost-saving process (Libra et al., 2011). Furthermore, HTC allows obtaining different materials with specific physicochemical properties according to reaction time (Antonietti, 2006).

Unlike the conventional carbonization process, which produces a high carbon content with aromatic features, HTC yields biochar-like material with functional groups or hydrochar (Sevilla \& Fuertes, 2009). Usually employed in nanochemical science, this technique has been shown to be exothermic in nature (Titirici et al., 2007). 
In order to make the hydrothermal process of biomass carbonization more efficient technologically and environmentally friendly, an innovative method named microwave-assisted hydrothermal carbonization (MAHC) was developed (Guiotoku et al., 2009). This method produces an aqueous suspension of carbon-rich materials with oxygen-substituted components. MAHC accelerates the production of functionalized and carbonized biomass by a factor of $10^{6}$ to $10^{9}$, under mild conditions, and is also an attractive technology for hydrochar production and, consequently, for soil carbon sequestration from biomass on a large scale (Guiotoku et al., 2009).

In conventional heating, heat is transferred to the surface of the material by conduction, convection or radiation, and to interior of the material by thermal conduction. However, microwave heating initially excites the outer layers of the molecules. The inner part of the material is warmed as heat is transferred from the outer layers inward. Since the heat is generated by bulk material, heating achieves a greater volume and can be more selective. These characteristics, when properly controlled, result in a more uniform product, with faster production in reduced physical space (Clarck \& Sutton, 1996).

The objective of this work was to characterize the morphology and molecular composition of the hydrochar produced by MAHC of cellulose.

\section{Materials and Methods}

Hydrothermal carbonization of $\alpha$-cellulose (Solucell, Bahia Pulp S.A., Camaçari, BA, Brazil) was carried out according to Guiotoku et al. (2009). Briefly: $500 \mathrm{mg}$ of cellulose were poured in a polytetrafluorethylene reaction vessel filled with $10 \mathrm{~mL}$ of citric acid solution $\left(1.5 \mathrm{~mol} \mathrm{~L}^{-1}\right)$. The suspensions were placed in a sealed reactor for microwave processing. The materials were hydrothermally carbonized using a microwave oven with a magnetron frequency of $2.45 \mathrm{GHz}, 1,000 \mathrm{~W}$ at maximum power, and $10-\mathrm{W}$ pulse controlled power fractions (Ethos Plus, Milestone, Inc., Monroe, $\mathrm{CT}$, USA). The system was heated to $85^{\circ} \mathrm{C}$ for $3 \mathrm{~min}$, then to $145^{\circ} \mathrm{C}$ for $9 \mathrm{~min}$, and to $200^{\circ} \mathrm{C}$ for $4 \mathrm{~min}$, with an isotherm for $240 \mathrm{~min}$ at $200^{\circ} \mathrm{C}$. After the carbonization process, the reactor was cooled at room temperature, and the carbonized materials were filtered with a cellulose ester filter $(0.45 \mu \mathrm{m})$ and subsequently washed until reaching neutral $\mathrm{pH}$. The solid products were dried $\left(105^{\circ} \mathrm{C}\right.$ for 12 hours). The morphology and microstructure of the MAHC product (hydrochar) was evaluated using a scanning electron microscope (SEM) (XL-30, Royal Philips Electronics, Amsterdam, The Netherlands).

In pyrolysis a small portion of hydrochar was poured into quartz tubes (c.a. 1/3 of tube volume), partly filled with quartz wool. Pyrolysis was carried out at $500^{\circ} \mathrm{C}$ for $10 \mathrm{~s}$, and the coil heater was set as $10^{\circ} \mathrm{C} \mathrm{ms}^{-1}$. The pyroprobe extra conditions were: interface of $290^{\circ} \mathrm{C}$, oven temperature of $290^{\circ} \mathrm{C}$, and transfer line of $290^{\circ} \mathrm{C}$ (CDS/Pyroprobe 5200, CDS Analytical, Inc., Oxford, PA, USA). The on-line pyrolysis products were analyzed using a gas chromatography tandem to an ion trap mass spectrometer (PolarisQ, Thermo Scientific, West Palm Beach, FL, USA), equipped with a capillary column TR5MS SPC $(30 \times 0.25 \mathrm{~mm}$; $25 \mu \mathrm{m}$ film thickness). The pyrolysis products were introduced via pyroprobe transfer line into a split/ splitless injector (split $1: 30 ; 290^{\circ} \mathrm{C}$ ). A GC oven was programmed from 45 (held for $2 \mathrm{~min}$ ) to $300^{\circ} \mathrm{C}$ at

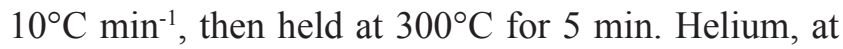
a constant flow of $1.0 \mathrm{~mL} \mathrm{~min}{ }^{-1}$, was the carrier gas. The GC-MS interface and ion source temperatures were 300 and $200^{\circ} \mathrm{C}$, respectively. The ion trap mass spectrometer was operated in the positive impact electronic mode at $70 \mathrm{eV}$, with a scanning range of $\mathrm{m} / \mathrm{z} 50-650$ in a 0.58 total scan time and emission current of $250 \mathrm{~mA}$. Peak identifications were aided by computerized mass spectra library (NIST 05) and by interpretation of mass fragments.

Solid state ${ }^{13} \mathrm{C}$ NMR spectroscopy experiments were carried out using a Varian $500 \mathrm{MHz}$ spectrometer (Varian, Palo Alto, CA, USA) at ${ }^{13} \mathrm{C}$ and ${ }^{1} \mathrm{H}$ frequencies of 125 and $500 \mathrm{MHz}$, respectively. The variable amplitude cross-polarization with magic angle spinning technique (VACP/MAS) was applied with a contact time of $1.0 \mathrm{~ms}$, a spinning speed of $15 \mathrm{kHz}$, acquisition times of $13 \mathrm{~ms}$, and recycle delays of $500 \mathrm{~ms}$. Recoupled dipolar dephasing (DD) experiments were carried out with a dipolar dephasing time of $70 \mu$ s. High power ${ }^{1} \mathrm{H}$ two-pulse phase modulation (TPPM) decoupling of $80 \mathrm{kHz}$ was applied in all experiments. Free induction decays were acquired with a sweep width of $50 \mathrm{kHz}$ and the number of scans was variable (minimal of 4,096 scans), according to the obtained signal/noise ratio. 


\section{Results and Discussion}

A relevant morphological change was detected in the carbonized product, since the raw material was characterized by a fibrous morphology (Figure $1 \mathrm{~A}$ ). The MAHC carbonized product of cellulose (hydrochar) at $200^{\circ} \mathrm{C}$ consists mainly of aggregate microspheres with about $2.0 \mu \mathrm{m}$ in diameter, as shown by scanning electron microscope (SEM) micrography (Figure $1 \mathrm{~B}$ ). A possible mechanism for the formation of these microspheres suggests that the dehydration reaction of polysaccharides produces primarily levoglucosan and 5-hydroxymethylfurfural (HMF) (Yao et al., 2007). The formation of HMF takes place via cellulose ring contraction by an acid-catalyzed intramolecular reaction, releasing one water molecule (Liu et al., 2005). After several dehydration


Figure 1. Scanning electron microscope (SEM) micrograph of cellulose raw material (A); and microwave-assisted hydrothermally carbonized cellulose (B). reactions, the molecules would undergo a process of re-polymerization to form spherical nuclei in order to minimize interfacial energy. The carbonization of these nuclei will then take place as they are generated, according to the degradation kinetics of cellulose. However, further investigations must be carried out on the kinetics degradation/generation of cellulose and its influence on the morphology of MAHC materials.

Pyrolysis of hydrochar yielded a total ion current chromatogram (TIC) with a large number of peaks with high background signal (Figure 2). Most of the pyrolysis products werefuran-like compounds. Themostintensive peaks were interpreted as 2,3-dihydro-furfuryl-ethanol and dimethyl-2,3-dihydro-2-acetyl-benzofuran (Figure 2, peak numbers 9 and 19, respectively). Several compounds were identified in the Py-GC-MS analysis (Table 1). For better comprehension, pyrolysis products were divided into five classes: A, alkyl furans; $\mathrm{B}$, oxygen-functionalized furans; C, benzenoids; D, benzofurans; and E, unknown compounds. Only the compounds with more than $1.0 \%$ of the total percentage area had their mass spectra analyzed. The sum of all peak areas greater than $1.0 \%$ was equal to $93.9 \%$ of the total area provided by the TIC. Eight chromatographic peaks, $27.2 \%$ of the total area, did not provide pure compounds; therefore, their mass spectra were not useful for interpretation. The major classes identified in the hydrochar sample were benzofurans, followed by oxygen-functionalized furans accounting for 32.1



Figure 2. Partial Py-GC-MS total ion current (TIC) of hydrochar. 
and $24.3 \%$, respectively. The minor classes were alkyl furans and benzenoids.

The pyrolytic furan-like and benzenoid compounds, also detected in the Py-GC-MS analysis of raw and carbonized cellulose, are from the $\mathrm{A}$ and $\mathrm{B}$ classes (Pastorova et al., 1994) (Table 1). However, levoglucosan, the main product detected by pyrolysis analysis of raw cellulose and other sugar markers (e.g. pyranones), was not identified in the hydrochar, indicating that all original material was modified during the hydrothermal treatment.

Furthermore, condensed aromatic compounds (e.g. naphthalene and phenanthrene), usually present in the pyrolysis analysis of macromolecular structure of carbonized cellulose, were also not detected. Pastorova et al. (1994) observed the presence of condensed aromatics in cellulose char yielded up to $270^{\circ} \mathrm{C}$. Perhaps, the low temperature used during the production of hydrochar $\left(200^{\circ} \mathrm{C}\right)$ was not enough to promote the formation of these aromatic components, but benzofuran-like structures conferred an aromatic characteristic in the hydrochar material (Table 1, class D). Moreover, aliphatic side chains were detected in a wide range of pyrolytic compounds, indicating that hydrochar structure is a heterogeneous polymer formed mostly by a mix of small clusters of aliphatic and benzofuran structures. In spite of the low temperature used, the results indicate that the hydrochar material did not preserve the original oligosaccharide structure of the starting material, and no strong evidence of charred cellulose was detected in the final hydrochar product.

The ${ }^{13} \mathrm{C}$ NMR spectra are characterized by the presence of two broadened peaks centered at 25 and $125 \mathrm{ppm}$ (Figure 3). The contribution of saturated ( $\mathrm{sp}^{3}$-hybridized carbons) aliphatic groups can be observed between 0 and $60 \mathrm{ppm}$. This region could be attributable to the methyl and ethyl substituents of the structures listed in Table 1 (peaks 1, 3-6, 9, 11, 16, 17, and 19). The presence of the resonance peaks at 112 and $140 \mathrm{ppm}$ is indicative of the olefinic $\mathrm{C}$ pairs, $\mathrm{C}-3 / \mathrm{C}-4$ and $\mathrm{C}-2 / \mathrm{C}-5$, of the furanyl structure, respectively. Therefore, based on the Py-GC-MS results, the peak at $129 \mathrm{ppm}$ is probably from single benzil-C and not from polycondensed aromatic structures, because, in this case, the peak must be upfield shifted (Freitas et al., 1999; Knicker et al., 2005; Smernik et al., 2006). In accordance with the Py-GC-MS results, which did not show any evidence of polycondensed aromatic structures, this kind of structure can be ruled out due to the unresolved and broad aryl signal with maximal at $129 \mathrm{ppm}$. Additionally, the thermal decomposition of the cellulose is prone to produce anhydro-oligosaccharides (Radlein et al., 1987) and, in the present case, these are probably in a condensed or substituted form, since in the spectrum after dipolar dephasing filtering, which shows only the unprotonated and mobile $\mathrm{C}$, almost all

Table 1. Identified compounds and their relative distribution in Py-GC-MS data of the microwave-assisted hydrothermal product of cellulose (hydrochar).

\begin{tabular}{|c|c|c|c|c|c|c|}
\hline Peak $^{(1)}$ & Retention time (min) & Compound & Class & Mass weight & Fragment ions & Percentage area \\
\hline$\overline{1}$ & 2.18 & 2,5-dimethyl-furan & A & 96 & $43,53,81$ & 2.45 \\
\hline 2 & 2.73 & Impure & $?^{(2)}$ & $-(3)$ & - & 1.33 \\
\hline 3 & 3.20 & methyl-benzene & $\mathrm{C}$ & 92 & 65,91 & 1.29 \\
\hline 4 & 3.85 & 2,3,5-trimethyl-furan & A & 110 & $43,67,95$ & 1.12 \\
\hline 5 & 4.44 & methyl-phenol & $\mathrm{C}$ & 108 & 77,107 & 1.07 \\
\hline 6 & 4.51 & 2-ethyl-furan & A & 96 & 53,81 & 1.82 \\
\hline 7 & 5.22 & Impure & $?$ & - & - & 2.65 \\
\hline 8 & 6.03 & 2-acetyl-furan & B & 110 & 67,95 & 3.1 \\
\hline 9 & 6.75 & 2,3-dihydro-furfuryl-ethanol & B & 114 & $53,68,96,113$ & 21.25 \\
\hline 10 & 7.06 & Impure & $?$ & - & - & 2.01 \\
\hline 11 & 7.56 & trimethyl-benzene & $\mathrm{C}$ & 120 & 77,105 & 2.52 \\
\hline 12 & 8.10 & Impure & $?$ & - & - & 3.42 \\
\hline 13 & 8.39 & Impure & $?$ & - & - & 5.57 \\
\hline 14 & 8.96 & Impure & $?$ & - & - & 2.13 \\
\hline 15 & 9.49 & Impure & $\mathrm{D}$ & - & - & 7.38 \\
\hline 16 & 9.55 & methyl-benzofuran & $\mathrm{D}$ & 132 & 77,103 & 2.57 \\
\hline 17 & 15.24 & methyl-2-ethyl-benzofuran (probably) & $\mathrm{D}$ & 160 & $77,103,131$ & 10.82 \\
\hline 18 & 18.70 & Impure & $?$ & - & - & 2.73 \\
\hline 19 & 20.81 & dimethyl-2,3-dihydro-2-acetyl-benzofuran & $\mathrm{D}$ & 190 & $91,119,147,175$ & 18.71 \\
\hline
\end{tabular}

${ }^{(1)}$ Corresponds to the peak numbers in Figure 2. ${ }^{(2)}$ Unknown compounds. ${ }^{(3)}$ Not determined. 
the $\mathrm{sp}^{2}$-hybridized $\mathrm{C}$ signals were retained. Another highlight from the dipolar dephasing spectrum is the important contribution of terminal methyl groups in the alkyl region, which presents significant signals after dipolar filtering, indicating alkyl groups with high mobility, corroborating the results from the Py-GC-MS analysis that indicates a wide range of aliphatic side chains in the pyrolytic products (Table 1).

The downfield signal at $151 \mathrm{ppm}$ can be assigned to the phenyl units (peaks 5, 16, 17, and 19) and to the C-2 of 2-acetyl-furan structures (peak 8) (Table 1). Other peaks are shown at 175 and $205 \mathrm{ppm}$ and are consistent with the presence of carboxyl and carbonyl functional groups, respectively (i.e., aliphatic carboxylic acids - 175 ppm; and aldehydes and ketones - 205 ppm). The detailed richness of the $\mathrm{sp}^{2}$-hybridized $\mathrm{C}$ region, compared to the symmetrical and featureless aryl signal of high carbonized materials, and the presence of aliphatic and oxygenated functional groups corroborate the low carbonization of the cellulose. This, together with the Py-GC-MS and SEM data, indicates that the produced hydrochar is probably reactive (carboxyl functionalities) in the sense of cation adsorption, contributing to soil cation exchange capacity. However, due to the low carbonization temperature, it is not so recalcitrant, and the possible lower $\mathrm{C}$ sequestration potential and long term effect of this material in the soil must be taken into account.

The NMR technique corroborates Py-GC-MS results, both confirming that the hydrochar product contains intermediated polymer built mainly of furan elements. The cellulose sign is also inconspicuous in the NMR

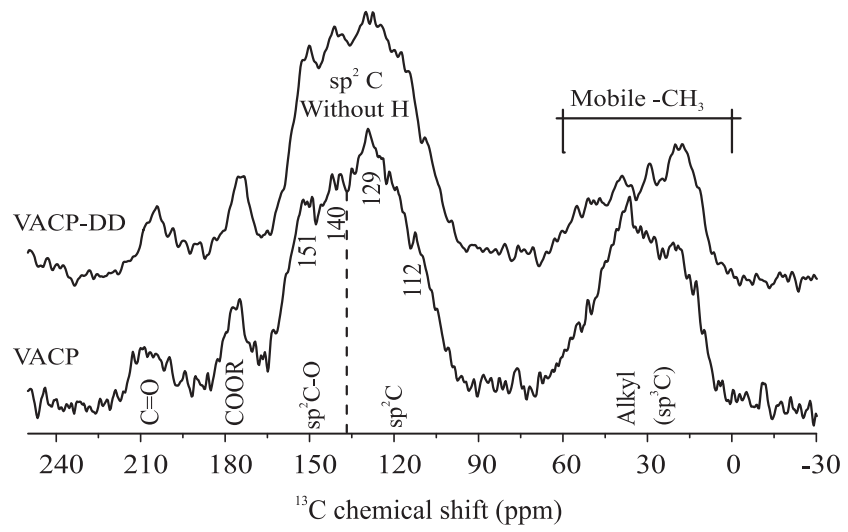

Figure 3. Full variable amplitude cross-polarization technique (VACP) spectrum of hydrochar, and the corresponding VACP (VACP-DD) spectra after dipolar dephasing with $70 \mu$ s of gated decoupling. spectra, since signals around $75 \mathrm{ppm}$ - indicative of the presence of hydroxylated methylene groups (O-alkyl) - were not prominent. The same results were observed in the pyrolysis analysis. Additionally, a considerable amount of levoglucosan and levoglucosenone (Lu et al., 2009) can be ruled out due to the lacking of the O-alkyl signal in the region of $70 \mathrm{ppm}$. It is important to note that the Py-CG-MS analysis provided a detailed view of the aromatic building blocks, indicating that hydrochar monomers are built on benzofuran-like components, whereas NMR provides valuable information on how these building blocks are connected in the hydrochar structure. The presence of carbonyl groups was detected by both analytical techniques, and the carbonyl function was identified by acetyl groups at the Py-GC-MS analysis, although organic acid groups are not promptly detected by pyrolysis due to decarboxylation during analysis (Kaal et al., 2008). These complementary results indicate that combining solid state ${ }^{13} \mathrm{C}$ NMR and Py-GC-MS analyses provides a broader view of the macromolecular structure of hydrochar.

According to Sevilla \& Fuertes (2009), the production of hydrochar from cellulose involves four steps: 1 , hydrolysis; 2 , dehydration and fragmentation of sugars; 3, polymerization or condensation of derivative sugars; and 4, aromatization. From the results obtained in the present study, it is possible to infer that the MAHC was able to carry out until steps 3 and 4; however, without recalcitrant aromatic structures normally seen in charred cellulose. Interestingly, it seems that hydrochar is formed at a lower temperature in the microwave environment $\left(200^{\circ} \mathrm{C}\right)$ than the hydrothermal treatment in autoclave condition, which, at $210^{\circ} \mathrm{C}$, yields a product with irregular morphology similar to that of pristine cellulose (Sevilla \& Fuertes, 2009). Hydrothermal carbonization is a novel route to produce carbon rich material and its use to produce a soil additive should be considered, mainly due to its functionalized chemical-nature product (hydrochar).

\section{Conclusions}

1. The microwave-assisted hydrothermal carbonized product of cellulose (hydrochar) does not retain the original structure of the cellulose and its chemical composition is not similar to that of common cellulose charcoal, being comprised by products of cellulose hydrolysis, dehydration, and condensation of derivative sugars.

Pesq. agropec. bras., Brasília, v.47, n.5, p.687-692, maio 2012 
2. The solid hydrochar product is not characterized by condensed aromatic structures that resemble charred materials; instead, it is characterized by clusters of aliphatic and aromatic domain, being the last one built mainly of furan elements.

3. Py-GC-MS and solid state ${ }^{13} \mathrm{C}$ NMR are complementary analytical tools to study the macromolecular structure of hydrochar.

4. Microwave-assisted hydrothermal carbonization yields a functionalized carbon rich material similar to that produced by the conventional hydrothermal process, but with milder conditions and shorter-time carbonization.

\section{Acknowledgements}

To Embrapa and Ministério da Agricultura Pecuária e Abastecimento, for financial support; to Ludmila de Araújo Ramos, from Bahia Pulp S.A., for providing the $\alpha$-cellulose sample; and to Centro Brasileiro de Pesquisas Físicas, for the $\mathrm{C}^{13}$ NMR analysis.

\section{References}

ANTONIETTI, M. Magic coal from the steam cooker. Max Planck Research, v.3, p.20-26, 2006.

BRIDGWATER, A.V. Renewable fuels and chemicals by thermal processing of biomass. Chemical Engineering Journal, v.91, p.87-102, 2003.

CLARCK, E.D.; SUTTON, W.H. Microwave processing of materials. Annual Review of Materials Science, v.26, p.299-331, 1996.

FREITAS, J.C.C.; BONAGAMBA, T.J.; EMMERICH, F.G. ${ }^{13} \mathrm{C}$ high-resolution solid-state NMR study of peat carbonization. Energy and Fuels, v.13, p.53-59, 1999.

FUNKE, A.; ZIEGLER, F. Hydrothermal carbonization of biomass: a summary and discussion of chemical mechanisms for process engineering. Biofuels, Bioproducts and Biorefining, v.4, p.160-177, 2010

GLASER, B.; BIRK, J.J. State of the scientific knowledge on properties and genesis of Anthropogenic Dark Earths in Central Amazonia (terra preta de Índio). Geochimica et Cosmochimica Acta, v.82, p.39-51, 2012.

GLASER, B.; HAUMAIER, L.; GUGGENBERGER, G.; ZECH, W. The 'Terra Preta' phenomenon: a model for sustainable agriculture in the humid tropics. Naturwissenschaften, v.88, p.37-41, 2001.

GUIOTOKU, M.; RAMBO, C.R.; HANSEL, F.A.; MAGALHÃES, W.L.E.; HOTZA, D. Microwave-assisted hydrothermal carbonization of lignocellulosic materials. Materials Letters, v.63, p.2707-2709, 2009.
KAAL, J.; MARTÍNEZ-CORTIZAS, A.; NIEROP, K.G.J.; BUURMAN, P. A detailed pyrolysis-GC/MS analysis of a black carbon-rich acidic colluvial soil (Atlantic ranker) from NW Spain. Applied Geochemistry, v.23, p.2395-2405, 2008.

KNICKER, H.; GONZÁLEZ-VILA, F.J.; POLVILLO, O.; GONZÁLEZ, J.A.;ALMENDROS, G. Fire-induced transformation of $\mathrm{C}$ - and N- forms in different organic soil fractions from a Dystric Cambisol under a Mediterranean pine forest (Pinus pinaster). Soil Biology and Biochemistry, v.37, p.701-718, 2005.

LIBRA, J.A.; RO, K.S.; KAMMANN, C.; FUNKE, A.; BERGE, N.D.; NEUBAUER, Y.; TITIRICI, M.-M.; FÜHNER, C.; BENS, O.; KERN, J.; EMMERICH, K.-H. Hydrothermal carbonization of biomass residuals: a comparative review of the chemistry, process and applications of wet and dry pyrolysis. Biofuels, v.2, p.89-124, 2011.

LIU, Q.F.; LV, C.X.; YANG, Y.G.; HE, F.; LING, L.C. Study on the pyrolysis of wood-derived rayon fiber by thermogravimetry - mass spectrometry. Journal of Molecular Structure, v.733, p.193-202, 2005.

LU, Q.; XIONG, W.-M.; LI, W.-Z.; GUO, Q.-X.; ZHU, X.-F. Catalytic pyrolysis of cellulose with sulfated metal oxides: a promising method for obtaining high yield of light furan compounds. Bioresource Technology, v.100, p.4871-4876, 2009.

NOVOTNY, E.H.; HAYES, M.H.B.; MADARI, B.E.; BONAGAMBA, T.J.; AZEVEDO, E.R. de; SOUZA, A.A. de; SONG, G.; NOGUEIRA, C.M.; MANGRICH, A.S. Lessons from the Terra Preta de Índios of the Amazon region for the utilisation of charcoal for soil amendment. Journal of the Brazilian Chemical Society, v.20, p.1003-1010, 2009.

PASTOROVA, I.; BOTTO, R.E.; ARISZ, P.W.; BOON, J.J. Cellulose char structure: a combined analytical Py-GC-MS, FTIR, and NMR study. Carbohydrate Research, v.262, p.27-47, 1994.

RADLEIN, D.; GRINSHPUN, A.; PISKORZ, J.; SCOTT, D.S. On the presence of anhydro-oligosaccharides in the sirups from the fast pyrolysis of cellulose. Journal of Analytical and Applied Pyrolysis, v.12, p.39-49, 1987.

SEVILLA, M.; FUERTES, A.B. The production of materials by hydrothermal carbonization of cellulose. Carbon, v.47, p.2281-2289, 2009.

SMERNIK, R.J.; KOOKANA, R.S.; SKJEMSTAD, J.O. NMR Characterization of ${ }^{13} \mathrm{C}$-benzene sorbed to natural and prepared charcoals. Environmental Science and Technology, v.40, p.1764-1769, 2006.

TITIRICI, M.-M.; THOMAS, A.; ANTONIETTI, M. Back in the black: hydrothermal carbonization of plant material as an efficient chemical process to treat the $\mathrm{CO}_{2}$ problem? New Journal of Chemistry, v.31, p.787-789, 2007.

YAO, C.; SHIN, Y; WANG, L.-Q.; WINDISCH, C.; SAMULES, W.D.; AREY, B.W.; WANG, C.; RISEN, W.M.; EXARHOS, G.J. Hydrothermal dehydration of aqueous fructose solutions in a closed system. Journal of Physical Chemistry C, v.111, p.15141-15145, 2007.

Received on January 28, 2011 and accepted on April 3, 2012 